\title{
Impact Evaluation of Artisanal and Small-Scale Mining on Land Use Land Cover: Implication for Sustainable Mining Environment in Niger State, Nigeria
}

\author{
H.M Liman', N.G Obaje ${ }^{2}$, A.A Sidi ${ }^{3}$ and P. Nwaerema ${ }^{4}$
}

\begin{abstract}
This study evaluated the impact of artisanal and small-scale mining on land use land cover as it applies to sustainable mining environment in Niger State, Nigeria. Thus, thirteen different mining locations covering the three geo-political locations were geo-referenced. The satellite imagery of Landsat TM and EMT+ from Global Land Cover Facilities (GLCF) and Earth Explorer (EE) for tri-images (1994, 2004 and 2014) at 30m resolution was obtained to establish the changes that occurred over the study years. Landsat imageries were analyzed with the aid of computer-based GIS ILWIS 3.3. The imageries were classified into degraded land, settlement, vegetation and water body. Results showed that in 1994, 33.4\% of the land use was degraded due to mining, settlement accounted for $3.7 \%$ and vegetation covered $59.2 \%$. In $2004,21.1 \%$ of the land was degraded, vegetation decreased from $59.2 \%$ in 1994 to $30.9 \%$ in 2004. In 2014, land degraded to $47.36 \%$, settlement expanded to $16.06 \%$, vegetation covered $24.22 \%$ and water body occupied $12.37 \%$ of the mining sites. Within the study period, mining sites increased from $30,000 \mathrm{~km}^{2}(33 \%)$ to $48,000 \mathrm{~km}^{2}(45 \%)$ indicating the severity of mining impact. Therefore, the government should develop strategic mining policy framework targeting a sustainable mining operation in Niger State.
\end{abstract}

Keywords: Mining Effects, Artisanal mining, Environment, Land degradation, Niger State.

\footnotetext{
1 Department of Geography, Ibrahim Badamasi Babangida University, Lapai, Nigeria.

2 Department of Geology, Ibrahim Badamasi Babangida University, Lapai Nigeria.

3 Department of Geology, Ibrahim Badamasi Babangida University, Lapai Nigeria.

4 Department of Geography, Ibrahim Badamasi Babangida University, Lapai, Nigeria.
}

Article Info: Received: November 22, 2020. Revised: January 4, 2021.

Published online: April 12, 2021. 


\section{Introduction}

In Nigeria, Artisanal and Small-scale Mining (ASM) is not a new phenomenon. The poor performance of the large-scale mining sector in the country, together with high unemployment rates, poverty, farm seasonality, lack of alternative livelihoods and little incentive to raise money for alternative livelihoods as well as little provision of basic life amenities have encouraged the growth of ASM in Nigeria [1]. Organized mining started in Nigeria around 1903 through private owned foreign companies. The first legislation on mining was enacted in 1946 and was only reviewed in 1999. Both Laws (1946 and 1999) have no provision for artisanal mining. Blacksmith Institute [3] defines ASM as mining activities that use rudimentary methods to extract and process minerals and metals on a small scale. According to the Nigerian Minerals and Mining Act (2007), ASM is a mining operation limited to the utilization of non-mechanized or low-level mechanized methods of reconnaissance, exploration and processing of mineral resources within a small-scale mining lease area. The artisanal and small-scale mining industry plays a prominent socio-economic role in the rural and impoverished regions of the world. Typically, in these areas, employment is scarce, salaries are low and the illiteracy is high. Intensive small-scale mining operations provide economic opportunities because wages are higher than those of the conventional agricultural and rural construction industries and employment is semi-permanent [14]. This however also affects the land as the average amount of cropland and pasture land per capita in 1970 was 0.4 and 0.8 ha and by 2010 this had decreased to 0.2 and 0.5 ha per capita, respectively [16].

Artisanal and small-scale mining has experienced explosive growth in recent years due to the rising values of mineral prices and the increasing difficulty of earning a living from agriculture and other rural activities. An estimated 40.5 million people were directly engaged in ASM in 2017, 30 million in 2014, 13 million in 1999 and 6 million in 1993; compares with 7 million people working in industrial mining in 2013 [7]. The devastating environmental and land use expansion for the activities of ASM in various parts of the world and Nigeria will continue to cause severe damage to the landscape and eventual destruction of the ecosystem. This indicates the rising number of people engaged in artisanal and small-scale mining. The peculiar rise in poverty and ASM will make more people to engage in ASM practices especial in the rural areas. Therefore, this study was to evaluate the impact of artisanal and small-scale mining on land use land cover as it applies to sustainable mining environment in Niger State, Nigeria. 


\section{The study Area}

The study was conducted in Niger State, located between Latitudes $8^{\circ} 20^{\prime \prime} \mathrm{N}$ and $10^{\circ} 30^{\prime} \mathrm{N}$ and Longitudes $3^{\circ} 20^{\prime} \mathrm{E}$ and $7^{\circ} 20^{\prime} \mathrm{E}$, situated in the north-central part of Nigeria (Figure 1). The hard rock of Precambrian basement complex underlies the study area at the northern edge of the Niger trough. The basement rocks comprise of the Migmatite Gneiss Complex, the Schist Belts and Older Granites [12]. These Precambrian basement rocks are overlain by sedimentary rocks in the southern portion and alluvium soil bordering the River Niger and its tributaries. The sedimentary rocks which are Cretaceous in age are made up of the Bida Sandstone at the base, followed successively upward by the Sakpe, Enagi and Batati Formations [12].

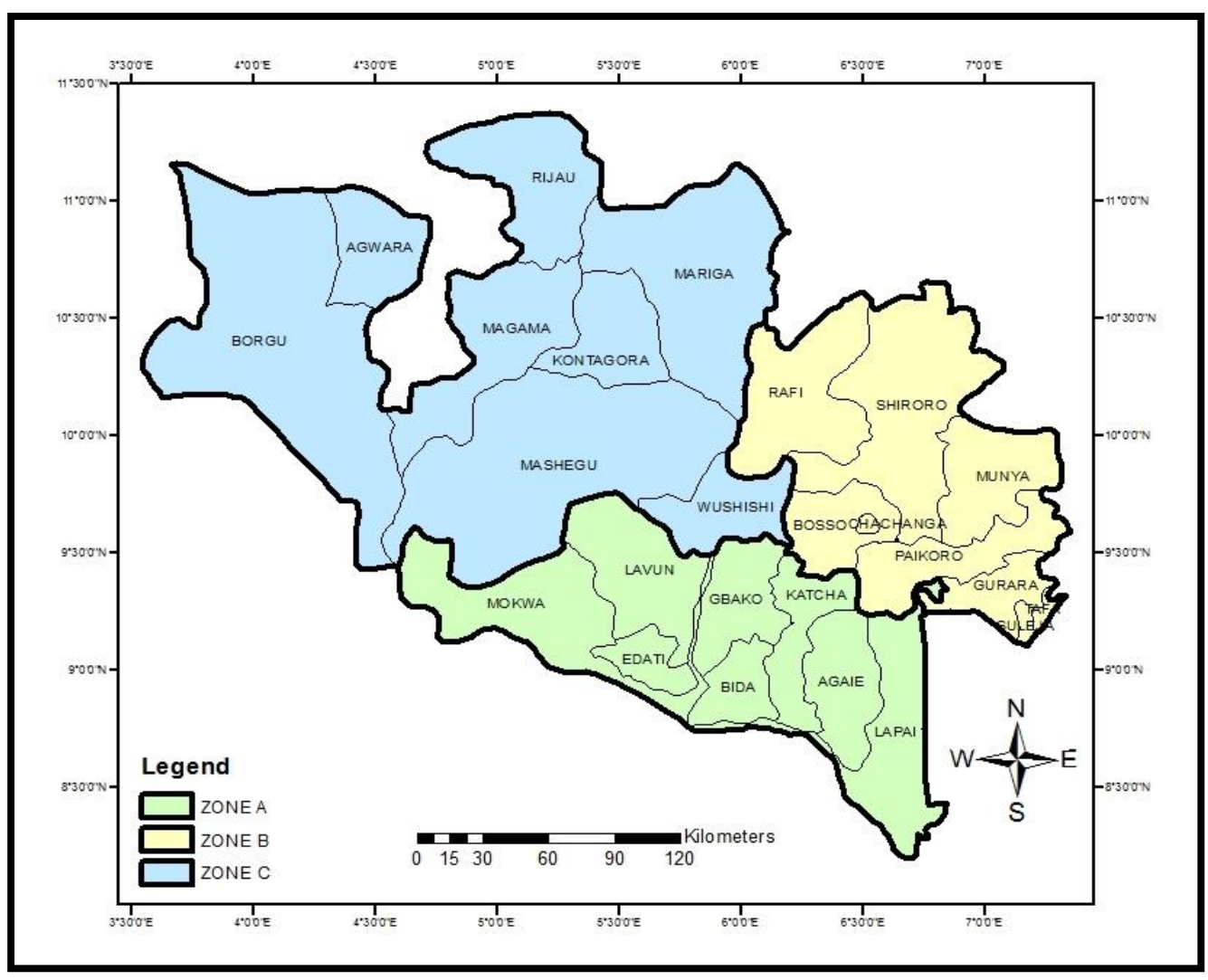

Figure 1: The study area (Ministry of Lands and Housing Minna, 2016). 


\section{Research Methodology}

A reconnaissance survey of thirteen different mining locations scattered in the three geo-political zones of Niger State was conducted considering the type of mineral mined, the location, the Local Government Area (LGA) which the geographical point coordinates were recorded. Satellite images of Land Sat TM and $\mathrm{EMT}^{+}$from Global Land Cover Facilities (GLCF) and Earth Explorer (EE) for tri-images (1994, 2004 and 2014) satellite images with 30m spatial resolution were obtained for the study to ascertain the changes that occurred in the environment before and after the mining activities. The spectral characteristics are shown in Table 1.

The Landsat imageries were analyzed with the aid of computer-based GIS ILWIS 3.3. This was used for radiometric enhancement, development of land use/land cover classification of the imageries of the study area for the years of 1994, 2004 and 2014. The imageries were classified using three bands of green-blue (1), green (2) and red (3) and categorized into four features namely: Degraded land, Settlement, Vegetation and Water body. Land cover and land use patterns on Earth reflect the interaction of human activities and the natural environment [1].

Table 1: Land Sat TM and ETM+ for 1994, 2004 and 2019 spectral consideration and sources.

\begin{tabular}{|c|c|c|c|c|}
\hline $\begin{array}{c}\text { Band } \\
\text { No }\end{array}$ & $\begin{array}{c}\text { Wavelength } \\
(\boldsymbol{\mu m})\end{array}$ & $\begin{array}{c}\text { Spectral } \\
\text { Region }\end{array}$ & $\begin{array}{c}\text { Spatial Resolution } \\
(\mathbf{M})\end{array}$ & Source \\
\hline 1 & $0.45-0.52$ & Blue-Green & 30 & $\begin{array}{c}\text { GLCF* and } \\
\text { EE* }^{*}\end{array}$ \\
\hline 2 & $0.52-0.60$ & Green & 30 & $\begin{array}{c}\text { GLCF* and } \\
\text { EE* }\end{array}$ \\
\hline 3 & $0.63-0.69$ & Red & 30 & $\begin{array}{c}\text { GLCF* and } \\
\text { EE* }\end{array}$ \\
\hline
\end{tabular}

${ }^{*} \mathrm{GLCF}=$ Global Land Cover Facilities; EE=Earth Explorer

\section{Results}

Table 2 gives information of the various minerals mined within the Local Government Areas and their geographical coordinates. The interpreted satellite data for the study are presented in Figures 2, 3 and 4, while the statistical analysis of environmental changes and land use resulting from small scale mining over the three periods are presented in Tables 3, 4 and 5.

Three ASM locations were selected within the study area reflecting the three (3) senatorial zones in the State. The selected locations were: Kataeregi which was between the Precambrian basement complex and sedimentary formation and located within N090 22'33" E060 17' 02"; Sarkin Pawa lied within Precambrian basement complex formation located within N10001'29" E07006'47' lying within Munya Local Government Area of the State; Leshibe lied within the Precambrian basement 
complex formation located within N10050' 49' 'E040 05'50', respectively. The result of the land use/land cover categorization indicated the identification of four classes of degraded land, settlement, vegetation and water body. These were used to assess the trend in land use/land cover change in the Area.

Table 2: Various Minerals Mined in the study area and the Geographical Coordinates.

\begin{tabular}{|c|c|c|c|c|}
\hline $\mathbf{S} / \mathbf{N}$ & Minerals & Location & LGA & $\begin{array}{c}\text { Geographic Point } \\
\text { Coordinates }\end{array}$ \\
\hline 1 & Tourmaline & Sarkin-Pawa & Munya & $\begin{array}{l}\mathrm{N} 10^{0} 01^{\prime} 29^{\prime \prime} \\
\mathrm{E} 07^{0} 06,47^{\prime}\end{array}$ \\
\hline 2 & Gold & Kataeregi & Katcha & $\begin{array}{l}\text { N09 }{ }^{0} 22^{\prime} 33^{\prime \prime} \\
\text { E06 }^{0} 17^{\prime} 02^{\prime \prime}\end{array}$ \\
\hline 3 & Gold & Leshibe & Borgu & $\begin{array}{l}\text { N09 }^{0} 59^{\prime} 35^{\prime \prime} \\
\text { E04 } 24^{\prime} 23^{\prime \prime}\end{array}$ \\
\hline 4 & Iron-Ore & Konkoso & Borgu & $\begin{array}{l}\mathrm{N} 10^{0} 50^{\prime} 49^{\prime \prime} \\
\mathrm{E} 04^{0} 05^{\prime} 50^{\prime \prime}\end{array}$ \\
\hline 5 & Gold & Danu & Paikoro & $\begin{array}{l}\text { N09 }^{0} 30^{\prime} 13^{\prime \prime} \\
\text { E06 }^{0} 33^{\prime} 00^{\prime \prime}\end{array}$ \\
\hline 6 & Gold & Mayaki & Lapai & $\begin{array}{l}\text { N08 } 0 \text { 50' 58”' } \\
\text { E06 } 42^{\prime} 04^{\prime \prime}\end{array}$ \\
\hline 7 & Kaolin & Gulu-Kandi & Lapai & $\begin{array}{l}\text { N08 } 36^{\prime} 54^{\prime \prime} \\
\text { E06 } 34^{\prime} 47^{\prime \prime}\end{array}$ \\
\hline 8 & Gold & Shakwata & Shiroro & $\begin{array}{l}\text { N09 } 9^{0} 42^{\prime} 36^{\prime \prime} \\
\text { E06 }^{0} 33^{\prime} 02^{\prime \prime}\end{array}$ \\
\hline 9 & Gold & Garun-Gabas & Rafi & 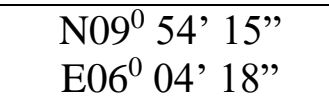 \\
\hline 10 & Topaz & Shadadi & Mariga & $\begin{array}{l}\mathrm{N} 10^{0} 39^{\prime} 54^{\prime \prime} \\
\mathrm{E}^{\circ} 5^{\circ} 43^{\prime} 51^{\prime \prime}\end{array}$ \\
\hline 11 & Copper & Shafini & Magama & $\begin{array}{l}\text { N09 }^{0} 55^{\prime} 19^{\prime \prime} \\
\text { E04 } 41 ' 12^{\prime \prime}\end{array}$ \\
\hline 12 & Iron-Ore & Malale & Borgu & $\begin{array}{l}\mathrm{N} 10^{0} 03^{\prime} 39^{\prime \prime} \\
\mathrm{E} 04^{0} 05^{\prime}, 23^{\prime \prime}\end{array}$ \\
\hline 13 & Manganese & Paiko & Paikoro & $\begin{array}{l}\mathrm{N} 10^{0} 03^{\prime} 39^{\prime \prime} \\
\mathrm{E} 04^{0} 05^{\prime}, 23^{\prime \prime}\end{array}$ \\
\hline
\end{tabular}

The land use/land cover satellite imagery in Figure 2 was captured in 1994 (A), 2004 (B) and 2014 (C) respectively. Figure 2 and Table 3 depicted the distribution of land use/land cover changes due to mining activities in the area. In 1994, 33.4\% of the land use degraded due to mining. Settlement accounts for $3.7 \%$, vegetal cover form $59.2 \%$ respectively. The smaller size of the settlement as at then suggested less migration of miners into the area. In 2004, the land cover was degraded by $21.1 \%$, the vegetal cover decreased from $59.2 \%$ in 1994 to $30.9 \%$ in 2004 , showing 
a difference of $28.3 \%$. Settlement size also increased about four-fold from $3.65 \%$ to $12.35 \%$ taking its toll on the decrease in vegetal cover. All these were due to increased ASM activities that span in the past 10 years. In 2014, the degraded land due to mining activities had reduced to about $37.8 \%$ due to the fact that as at 2006, government clamped down on ASM activities and closed down the sites. This period had regeneration of vegetation resulting in an increase of about $3.2 \%$ above that of 2004. Settlement also increased by $9.0 \%$, because between 2004 and 2014 more miners migrated into the area to engage in their mining activities. Increased in their population could lead to further degradation of the land and water bodies that government clamped down on them to halt the mining activities.

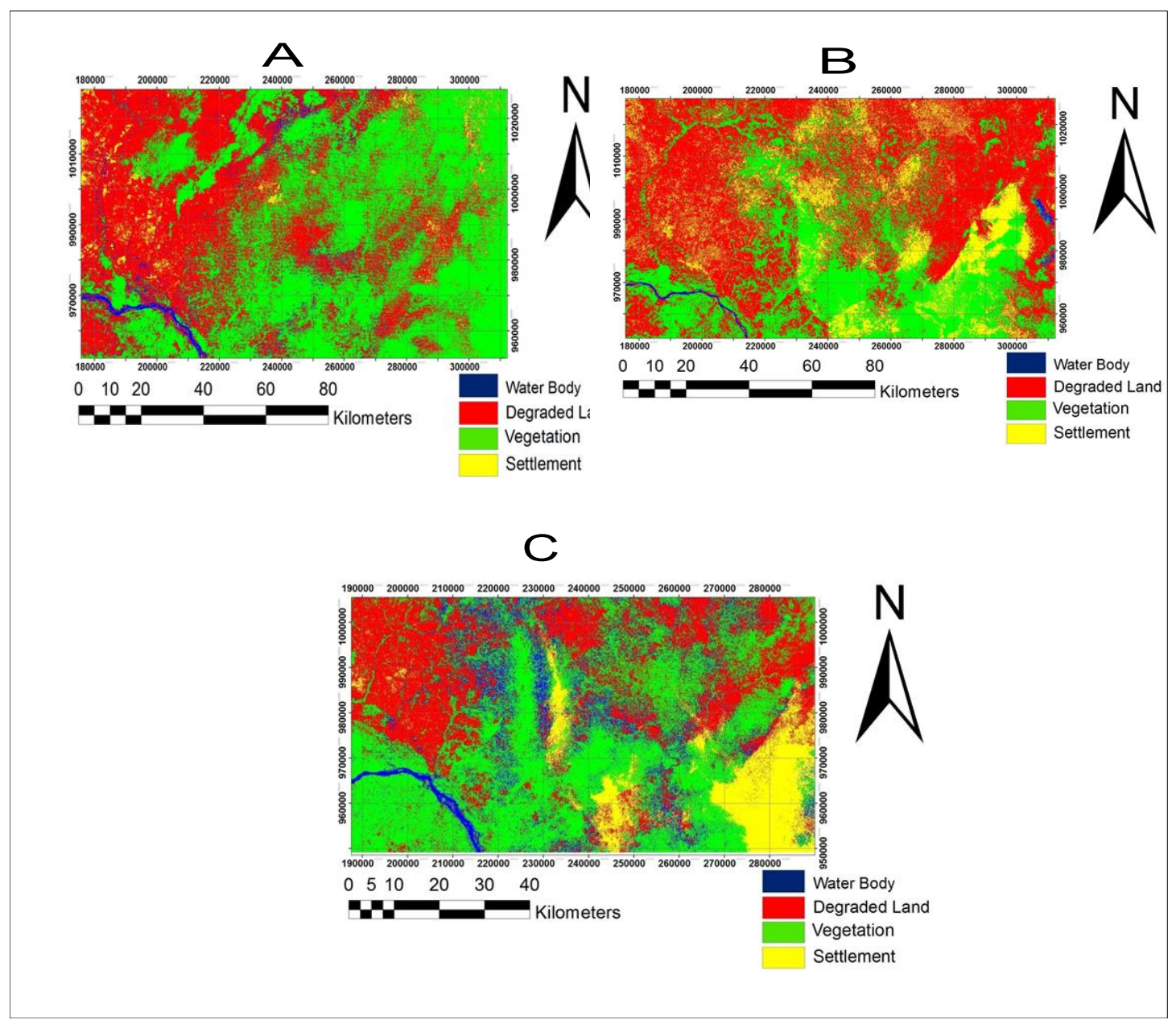

Figure 2: Land use/ Land Cover Classification of Kataeregi $(A=1994, B=2004, C=2014)$. 
Table 3: Categorized land use/ land cover for Kataeregi in 1994, 2004 and 2014.

\begin{tabular}{|c|c|c|}
\hline Category & Area covered $\left(\mathrm{m}^{2}\right)$ & $\%$ of Area covered \\
\hline \multicolumn{3}{|c|}{ Categorized land use/ land cover statistics for Kataeregi (1999) } \\
\hline Degraded land & $4,860,503,100$ & 33.36 \\
\hline Settlement & $483,598,000$ & 3.63 \\
\hline Vegetation & $86,713,757,000$ & 59.21 \\
\hline Water body & $553,349,700$ & 3.80 \\
\hline \multicolumn{3}{|c|}{ Categorized land use/ land cover statistics for Kataeregi (2004) } \\
\hline Degraded land & $7,971,060,600$ & 54.5 \\
\hline Settlement & $1,848,966,200$ & 12.33 \\
\hline Vegetation & $4,522,374,900$ & 30.93 \\
\hline Water body & $190,545,400$ & 2.23 \\
\hline \multicolumn{3}{|c|}{ Categorized land use/ land cover statistics for Kataeregi (2014) } \\
\hline Degraded land & $5,524,207,200$ & 37.78 \\
\hline Settlement & $3,125,274,300$ & 21.37 \\
\hline Vegetation & $4,859,631,000$ & 33.23 \\
\hline Water body & $1,113,834,600$ & 7.62 \\
\hline
\end{tabular}

The land use/land cover change of Sarkin Pawa was shown in Figure 3. Table 4 showed the percentage distribution of land use/land cover change due to mining activities in Sarkin Pawa. During the period of 1994, 28.6\% was degraded as a result of mining activities, settlement accounted for $9.5 \%$ and vegetal cover accounted for $53 \%$. The vegetal cover was much in 1994 because during the period, mining had not started and the influx of people was not much. Water body occupied $9.27 \%$ of the total area. In 2004, land cover was further degraded by $10 \%$ due to mining activities, the vegetal cover decreased by $12.4 \%$, and settlement size increased due to the influx of miners. Water body as at this period increased by $0.2 \%$, furthermore, the degraded land in 2014 was $44.5 \%$, therefore, the period between 2005 and 2009 marked a period of serious mining activities in Sarkin Paw. Vegetal cover decreased and settlement cover increased due to the increased number of miners but water body decreased greatly from $9.5 \%$ in 2004 to $6.4 \%$ in 2014 . Environmental indicators should reflect all elements of the chain between human activities, their environmental impacts, and the societal responses to these impacts [4]. Migration in its various forms is the most important demographic factor causing land-use change at timescales of a couple of decades [5]. 
Table 4: Categorized land use/land cover for Sarkin Pawa, 1994, 2004 and 2014.

\begin{tabular}{|c|c|c|}
\hline Category & Area covered $\left(\mathrm{m}^{2}\right)$ & $\%$ of Area covered \\
\hline \multicolumn{3}{|c|}{ Categorized land use/land cover statistics for Sarkin Pawa (1999) } \\
\hline Degraded land & $1,763,129,144.3$ & 28.64 \\
\hline Settlement & $584,821,624.5$ & 9.50 \\
\hline Vegetation & $3,238,478,925.8$ & 52.60 \\
\hline Water body & $570,474,040.5$ & 9.27 \\
\hline \multicolumn{3}{|c|}{ Categorized land use/land cover statistics for Sarkin Pawa (2004) } \\
\hline Degraded land & $1,287,468,900$ & 38.63 \\
\hline Settlement & $390,537,900$ & 11.72 \\
\hline Vegetation & $1,338,438,600$ & 40.16 \\
\hline Water body & $316,119,600$ & 9.49 \\
\hline \multicolumn{3}{|c|}{ Categorized land use/land cover statistics for Sarkin Pawa (2014) } \\
\hline Degraded land & $3,001,986,000$ & 44.46 \\
\hline Settlement & $1,214,420,400$ & 17.99 \\
\hline Vegetation & $2,103,761,700$ & 31.16 \\
\hline Water body & $431,558,100$ & 6.39 \\
\hline
\end{tabular}

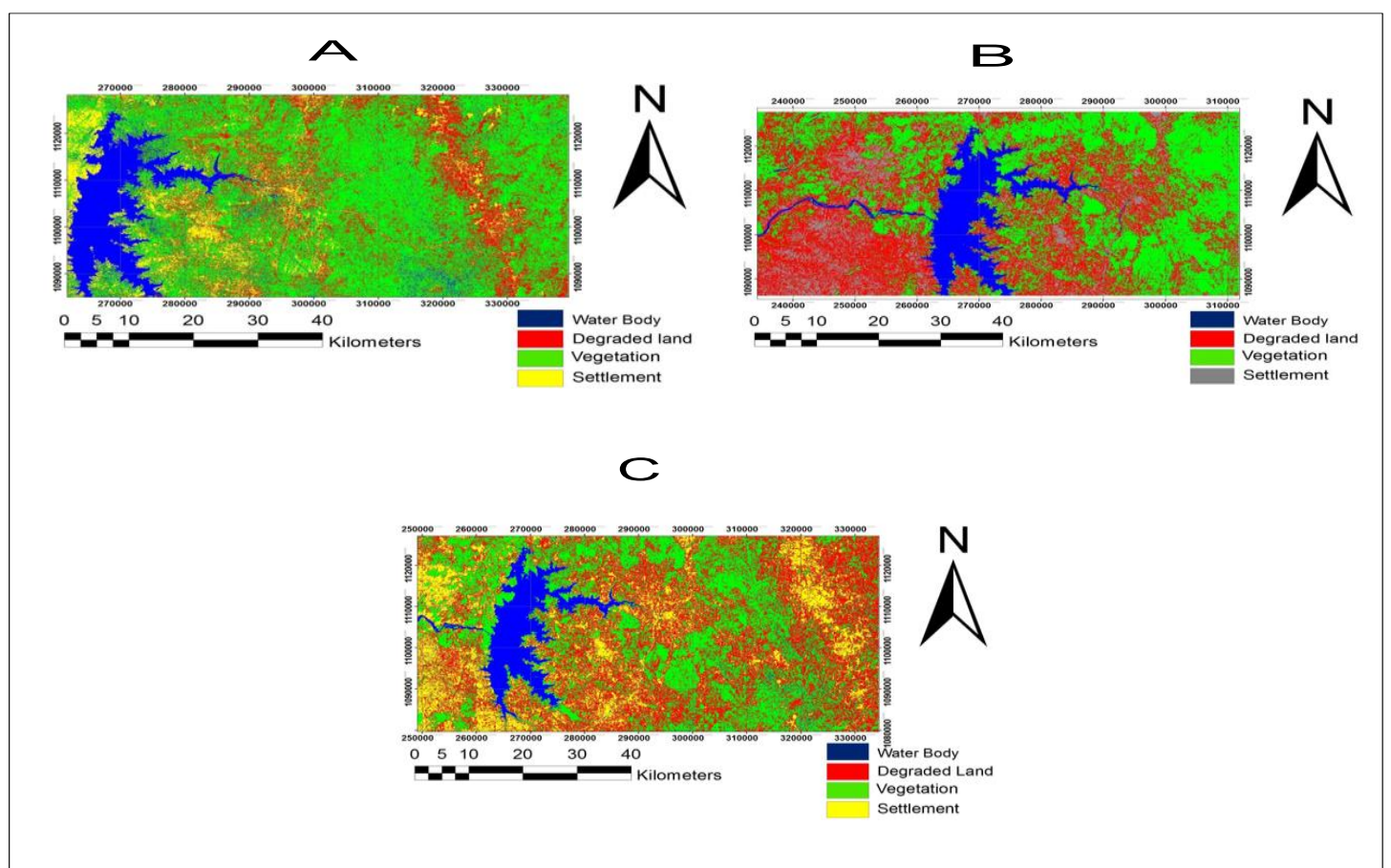

Figure 3: Land use/ Land Cover Classification of Sarkin Pawa ( $A=$ 1994, $B=2004, C=2014)$. 
Figure 4 and Table 5 showed the distribution of land use/land cover due to artisanal and small mining activities in Leshibe. In 1994, the degraded land was 45\%, settlement was $9.5 \%$, and vegetal cover was $32 \%$ as well as $14 \%$ for water body. Settlement at this period was not much and the vegetation was not distorted then; this was because mining of Iron ore had not commenced. Serious mining activities did not start until 2005 when Iron ore was discovered which vegetal cover was $32.06 \%$, settlement $10.5 \%$ and water body was about $13 \%$. In 2014, the degraded land was $47.36 \%$, settlement was $16.06 \%$, vegetation had $24.22 \%$ and water body occupied $12.37 \%$ of the mining site.

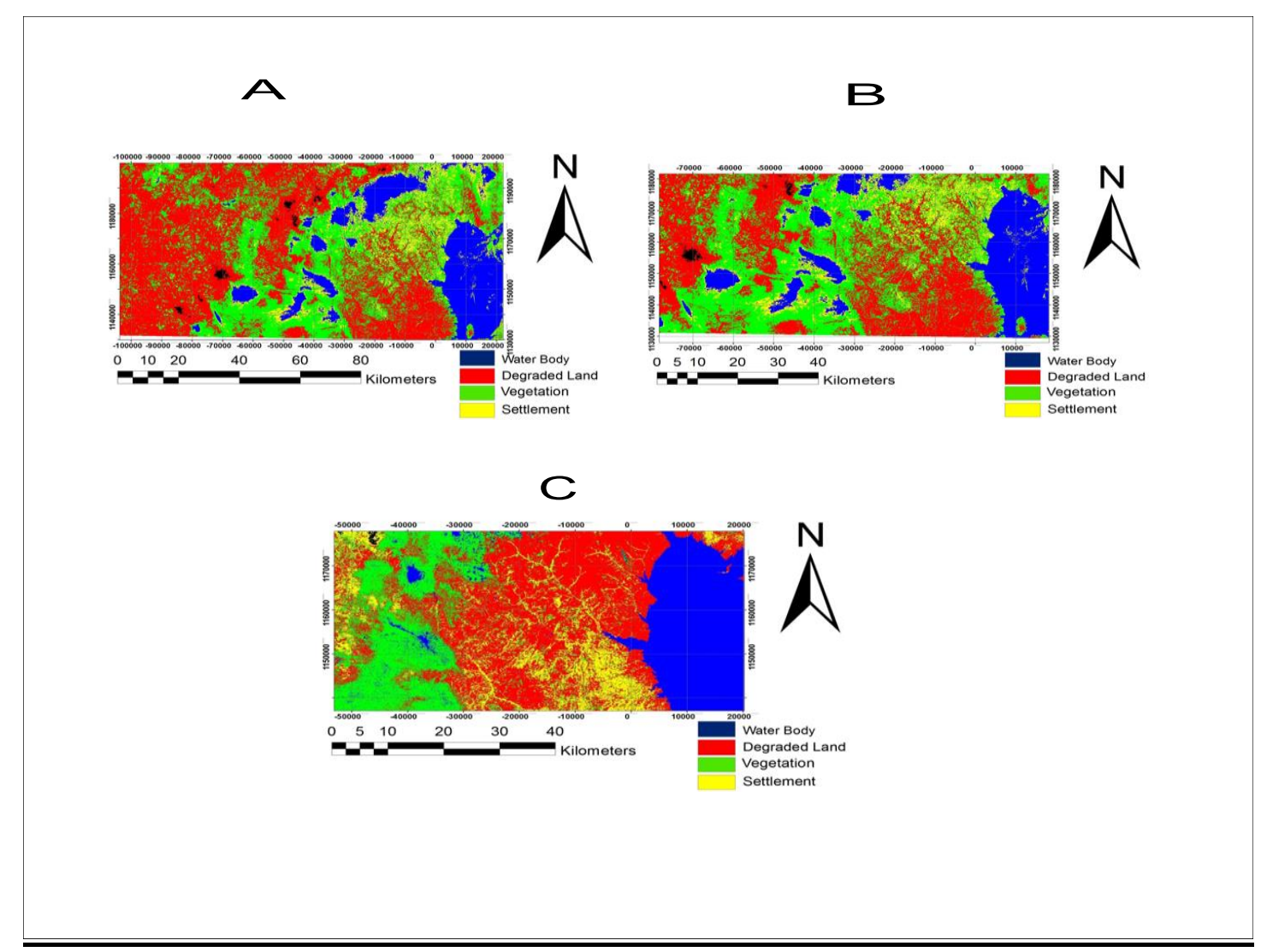

Figure 4: Land use/ Land Cover Classification of Leshibe $(A=1994, B=2004, C=2019)$. 
Table 5: Categorized Land Use/Land Cover for Leshibe 1999, 2004, 2014.

\begin{tabular}{|c|c|c|}
\hline Category & Area covered $\left(\mathrm{m}^{2}\right)$ & $\%$ of Area covered \\
\hline \multicolumn{2}{|c|}{ Categorized land use/ land cover statistics for } & es for Leshibe (1999) \\
\hline Degraded land & $4,429,995,300$ & 44.55 \\
\hline Settlement & $945,715,500$ & 9.51 \\
\hline Vegetation & $3,184,763,400$ & 32.03 \\
\hline Water body & $1,384,072,200$ & 13.92 \\
\hline \multicolumn{3}{|c|}{ Categorized land use/ land cover statistics for Leshibe (2004) } \\
\hline Degraded land & $4,429,995,300$ & 44.55 \\
\hline Settlement & $1,043,784,100$ & 10.49 \\
\hline Vegetation & $3,187,836,000$ & 32.06 \\
\hline Water body & $1,282,931,000$ & 12.90 \\
\hline \multicolumn{3}{|c|}{ Categorized land use/ land cover statistics for Leshibe (2014) } \\
\hline Degraded land & $4,113,042,300$ & 47.36 \\
\hline Settlement & $2,193,381,900$ & 16.06 \\
\hline Vegetation & $2,408,296,500$ & 24.22 \\
\hline Water body & $1,229,825,700$ & 12.37 \\
\hline
\end{tabular}

\subsection{Discussion}

The results of this study evaluated the land use land cover in the characteristics of degraded land, settlement, vegetation and water body respectively. The issue of land degradation results to the reduction of available land and decrease in the value of land in terms of devastation of the natural biophysical components of the surface area. Humans have altered land cover for centuries, but recent rates of change are higher than ever [6].

Mining causes the release of chemical hazards, burrowing of pits and quantitative generation of sand waste occupying the mining site. The result of this study shows that in 1994, 33.4\% of the land use degraded due to mining, experienced degradation of $21.1 \%$ in 2004 and $37.8 \%$ in 2014 respectively. This is in tandem with the findings of [10] that assessed the effects of gold mining on land use/land cover changes of East Cameroon from 1987 to 2017 using Landsat imageries. It revealed that settlement surface expanded with other environmental changes between the years 2000 to 2017 as well as significant spatio-temporal alteration of land use land cover in the study area. The study recommended the use of Landsat imageries in LULC studies.

The operation of mining activities tends to reduce the density and expanse of vegetal cover over the years. Water bodies are either increased due to burrowing of new pits or reduced by covering the existing water bodies with debris and sand from excavated pits. The results of this study show that vegetation decreased from 59.2\% in 1994 to $30.9 \%$ in 2004. In 2004 vegetation covered $24.22 \%$ and water body occupied $12.37 \%$ of the mining sites. Ani and Sunil [2] investigated the impact of 
open cast coal mines on land use/land cover using remote sensing and GIS technique. The findings show that thickly covered vegetation areas were converted to mining lands and mining overburden. The water bodies expanded from $151.898 \mathrm{~km}^{2}$ to $321.568 \mathrm{~km}^{2}$ due to excavation of pits scattered across the mining area. Peprah [15] investigated the LULC from surface mining and its environs in the western region of Ghana. It shows that in 1990, forest covered 33119.8ha (29.25\%) and decreased by $10 \%$ in the year 2000 between 1990 to 2010, the total mining area expanded from 90.27ha (1990) to 3671.28ha (2010) respectively indicating the impact of mining to land use. Remediation of the potential environmental impacts, for example through water treatment and ecological restoration, can have positive net effects on environmental systems [8]. Mine abandonment, decommissioning and repurposing can also have both positive and negative social impacts. Examples of negative impacts include loss of jobs and local identities [9], while positive impact can include opportunities for new economic activities [11], e.g. in the repurposing of mines to become tourist attractions.

\section{Conclusions}

This investigation is on the impact of artisanal and small-scale mining on land use land cover as it affects sustainable mining environment in Niger State, Nigeria. The environmental and socio-economic effects of ASM in Niger State are enormous, as a wide range of biophysical and socio-economic components of the environment are affected. ASM activities produce massive solid wastes and pits which cause environmental degradation. Thus, ASM contributes to river siltation, deforestation, loss of biodiversity, soil erosion; pollution of sources of drinking water. ASM has adverse effects on the health of the people by way of chemical poisoning, physical injuries, impaired hearing, injuries from bad equipment and poor knowledge of equipment operation and death, mining collapse and rock falls including use of hard drugs. The mining pits constitute sites for insect breeding and diseases including water-borne diseases. However, the period of 1999 to 2014 experienced massive expansion of mining sites with severe changes in the land use land cover of the area. Mining activities have attracted settlement expansion and decreased water bodies and vegetal cover, thereby, altering the biophysical features of the natural environment. Generally, the degraded land covers between $30,000 \mathrm{~km}^{2}$ and $48,000 \mathrm{~km}^{2}$ accounting for $33 \%$ and $45 \%$ of the total land area of the mining sites indicating the severity of impact of mining activities. Therefore, the government and stakeholders should develop workable ASM mining policy framework targeting sustainable ASM operations in Niger State.

\section{Acknowledgement}

This research was funded by Tertiary Education Trust Fund (TETFUND), Nigeria. 


\section{References}

[1] Alonso-Pérez, F., Ruiz-Luna, A., Turner, J., Berlanga-Robles, C. A. and Mitchelson-Jacob, G. (2003). Land covers changes and impact of shrimp aquaculture on the landscape in the Ceuta coastal lagoon system. Ocean \& Coastal Management. Vol. 46, No.6-7, December, pp.583-600.

[2] Ani, C. and Sunil, K. K. (2010). Impact Analysis of Open Cast Coal Mines on Land Use/Land Cover using Remote Sensing and GIS Technique: A Case Study. International Journal of Engineering Science and Technology. Vol. 2, No.12, December, pp.7171-7176, http://www.ijest.info/docs/IJEST10-02-12090.pdf.

[3] Blacksmith Institute (2011). Artisanal Gold Mining. Blacksmith Institute, New York.

[4] Gabrielsen, P. and Bosch, P. (2003). Environmental indicators, typology and use in reporting. Copenhagen: EEA.

[5] Geist, H., J. and Lambin, E. F. (2002). Proximate causes and underlying driving forces of tropical deforestation. Bioscience, Vol. 52, No.2, February, pp.143-150.

[6] Hansen, M. C., Stehman, S.V. and Potapov, P.V. (2010). Quantification of global gross forest cover loss. Proceedings of the National Academy of Sciences of the United States America. Vol.107, May, pp.8650-8655.

[7] International Institute for Environment and Development (IIED) (2018). Global Trends in Artisanal and Small-Scale Mining (ASM): A review of key numbers and issues. January 2018.

Retrieved from https://www.iisd.org/publications/global-trends-artisanal-andsmall-scale-mining-asm-review-key-numbers-and-issues

[8] Jain, R., Cui, Z. and Domen, J. (2016). Environmental impact of mining and mineral processing: management, monitoring, and auditing strategies. Amsterdam Elsevier, pp.53-157.

[9] Keeling, A. and Sandlos, J. (2001). Ghost towns and zombie mines: the historical dimensions of mine abandonment, reclamation, and redevelopment in the Canadian North. In: Bocking S, Martin B, editors. Ice Blink: Navigating Northern Environmental History, pp.377-420.

[10] Marc, A. K., Salomon, C. N. F., Moyosore, O. A., Olatubara, C. O., Nzali, S., Adeola, A. and Muhammad, K. (2020). Evaluation of land use/land cover changes due to gold mining activities from 1987 to 2017 using Landsat imagery, East Cameroon.

Geo Journal, Vol.85, pp.1097-1114. doi.org/10.1007/s10708-019-10002-8.

[11] Mitchell, C. J., and O'Neill, K. (2017). The Sherriff Creek Wildlife Sanctuary: further evidence of mine-site repurposing and economic transition in northern Ontario. Extr Ind Soc, Vol. 4, pp.24-35.

[12] Obaje, N. G. (2009). Geology and Mineral Resources of Nigeria. Springer Dordrecht, Heidelberg, London, New York. 
[13] Oramah, I. T., Richards, J. P., Summers, R. and Garvin, T. (2015). Artisanal and Small-Scale Mining in Nigeria: Experiences from Niger, Nasarawa and Plateau States. Extractive Industries and Society, Vol. 2(4), pp.694-703. doi.org/10.1016/j.exis.2015.08.009.

[14] Owusu-Koranteng, D. (2008). Mining is killing Agriculture. A press Release by WACAM. May 2008.

[15] Peprah, P. (2015). Assessing Land Cover Change Resulting from Surface Mining Development: A Case Study of Prestea and Its Environs in the Western Region of Ghana.

(Published Thesis, Kwame Nkrumah University of Science and Technology). Retrieved from http://dspace.knust.edu.gh/bitstream/123456789/8623/1/ASSESSING\%20LA ND\%20COVER\%20CHANGE\%20RESULTING\%20FROM\%20SURFACE \%20MINING\%20DE.pdf.

[16] The European environment-state and outlook 2010: synthesis (2010). Copenhagen, EEA, 212. 